\title{
ADMINISTRATIVE AND LEGAL ASPECTS OF THE ACTIVITY OF THE HIGH ANTI-CORRUPTION COURT AND OTHER ANTI-CORRUPTION BODIES OF UKRAINE IN THE CONTEXT OF EUROPEANIZATION
}

\author{
Mykhailo Kosiuta ${ }^{1}$, Lyubomyr Sopilnyk ${ }^{2}$, Solomiya Denys ${ }^{3}$, Rostyslav Sopilnyk ${ }^{4}$, Roman Zayats ${ }^{5}$
}

Received: 2021-02-14

Accepted: 2021-03-25

DOI: http://doi.org/10.46489/gpj.2021-1-1-1

Abstract. The establishment of the High Anti-Corruption Court in Ukraine was a radical step for Ukraine in the fight against corruption. This fact has led to many discussions and debates in scientific circles. The purpose of the article is to administrative and legal characteristics of the legal status of the High Anti-Corruption Court and other Anti-Corruption Bodies of Ukraine and prospects it's activity in the context of Europeanization. The chosen methodology helped to identify the historical origins of corruption; to outline the main features and establish the concept of "corruption"; to analyze the experience of European countries in establishing a system of anti-corruption bodies; to make proposals for reforming the current system of anti-corruption bodies of Ukraine in the context of Europeanization of administrative law. We believe that a key point in the process of improving the effectiveness of the fight against corruption in Ukraine is the need to implement the experience of European countries also in terms of informing and training civil servants professional ethics, awareness and legal culture. The high authority of anti-corruption bodies, as evidenced by the analyzed practice of EU countries (including Denmark), determines the effectiveness of the fight against corruption. Such a system of anti-corruption institutions will help to clearly establish powers, avoid conflicts of interest and bureaucratic schemes, increase the targeted use of budget funds, facilitate citizens' access to relevant bodies with complaints about corruption offenses, and eliminate the privileged status of corrupt officials in the administration of justice.

Keywords: corruption, historical origins, anti-corruption bodies, international experience, anti-corruption bodies of Ukraine

\footnotetext{
${ }^{1}$ Mykhailo Kosiuta, D.Sc. (Law), Professor, Professor of Department of Organization of Judicial, Law Enforcement Agencies and the Bar of National University "Odesa Law Academy”, 23 Fontanskaya road Str., Odesa, 65009, Ukraine, kosytamv@gmail.com, ORCID: https://orcid.org/0000-0001-8021-0873

${ }^{2}$ Lyubomyr Sopilnyk, D.Sc. (Law), D.Sc. (Engineering), Professor, Professor of the Department of Administrative Law and Process, Financial and Information Law of Lviv University of Business and Law, 99 Kulparkivska Str., Lviv, 79021, Ukraine, sopilnyk01@gmail.com, ORCID: http://orcid.org/0000-0001-6581-7255

3 Solomiya Denys, PhD (Law), Lecturer, Ivan Franko National Univetsity of Lviv, 19 Sichovykh Striltsiv Str., Lviv, 79007, Ukraine, solomiyal11201@gmail.com, ORCID: https://orcid.org/0000-0001-6079-2300

${ }^{4}$ Rostyslav Sopilnyk, D.Sc. (Law), Professor, Professor of the Department of Judiciary, Prosecution and Advocacy of Lviv University of Business and Law, 99 Kulparkivska Str., Lviv, 79021, Ukraine, rostyslav.sopilnyk@ukr.net, ORCID: https://orcid.org/0000-0001-9942-6682

5 Roman Zayats, D.Sc. (Law), Professor, Professor of the Department of Administrative Law and Process, Financial and Information Law of Lviv University of Business and Law, 99 Kulparkivska Str., Lviv, 79021, Ukraine, roman.zayats@ukr.net, ORCID: http://orcid.org/0000-0002-4726-6362
} 


\section{INTRODUCTION}

The establishment of the High AntiCorruption Court in Ukraine was a radical step for Ukraine in the fight against corruption. This fact has led to many discussions and debates in scientific circles. Today, the questions are: "Whether such a step was justified? Whether the system of existing anti-corruption bodies is effective?" This phenomenon causes significant damage to public interests, provided it is widespread. Unfortunately, today there is a tendency to increase the level of corruption in Ukraine. This fact negatively affects the economic processes in the country, slows down the path to membership in the European Union, and generally undermines the basic principles of the rule of law. Ukraine's anti-corruption system has undergone significant changes over the past six years. However, there are significant shortcomings of an organizational and legal nature in the activities of anti-corruption bodies, based on the inconsistency of powers due to their excessive number and inadequate legal support. These problems lead to the spread of corruption and a low level of public confidence in Ukraine's anti-corruption bodies. That is why there is an urgent need to reform the current system of anticorruption bodies, which justifies the relevance of the chosen topic. The experience of European countries with low levels of corruption and those that have taken significant steps to reduce them is a good example for Ukraine. In our opinion, in the context of Europeanization of administrative law, it is expedient to implement the achievements of European countries in the current legislation of Ukraine and to take into account the historical, political, and cultural development of Ukrainian society.

Therefore, the purpose of the article is to administrative and legal characteristics of the legal status of the High AntiCorruption Court and other AntiCorruption Bodies of Ukraine and prospects it's activity in the context of Europeanization.

\section{METHODOLOGY}

In the process of research on this topic were used general scientific research methods, which include: methods of empirical research, theoretical knowledge and general methods, in particular:

- abstraction - used in the study of the High Anti-Corruption Court and other bodies of current anti-corruption system of Ukraine and foreign countries in order to further develop proposals for its reform;

- analysis - used in the study of the conceptual apparatus of corruption, historical aspects of corruption as a social phenomenon, anti-corruption bodies and the specifics of legal regulation of the system and activities of anti-corruption bodies in current legislation of Ukraine and European countries;

- deduction - used in the study of theoretical aspects of corruption of the High Anti-Corruption Court and other bodies of current anti-corruption system of Ukraine and foreign countries;

- induction - used to clarify the shortcomings of the High Anti-Corruption Court and other bodies of current anticorruption system of Ukraine and foreign countries, which allowed to draw conclusions about the state of the current system of anti-corruption bodies in Ukraine;

- historical method - in determining the origins and formation of corruption as a negative social phenomenon;

- logical method - used in theoretical form for the purpose of chronological presentation of historical aspects of the emergence and spread of corruption;

- forecasting - on the basis of available data the own position concerning the further prospects of development of system of anti-corruption bodies in the context of Europeanization of administrative law is described; 
- synthesis - used in generalizing the signs of corruption in order to derive the concept of "corruption", as well as in clarifying the legal status of anti-corruption bodies in the context of forming them into an effective system;

- generalization - used in the study of the experience of some European countries regarding the current systems of anti-corruption bodies in order to further apply certain aspects of reforming the system of anti-corruption bodies in Ukraine.

The chosen methodology helped: to identify the historical origins of corruption; to outline the main features and establish the concept of "corruption"; to analyze the experience of European countries in establishing a system of anti-corruption bodies; to make proposals for reforming the current system of anti-corruption bodies of Ukraine in the context of Europeanization of administrative law.

\section{RESULTS}

The definition of "Europeanization" was proposed by R. Ladrech. Europeanization, according to the scientist, is "a gradual process that reorients the direction and forms of (domestic) policies to the level at which European political and economic dynamics grow into part of the organizational (constructive) logic of national policy and its formation" (Betsa, 2009, p. 36; Mikhel, 2011, p. 22).

Y. Yurinets considers the Europeanization of administrative law as the assimilation of the European style of legal thinking, law-making practice, and law enforcement in the activities of public administration (Yurinets, 2015, p. 80).

Ukraine is a member state of the Council of Europe (hereinafter - the CoE). Accordingly, the decisions of the Council of Europe and the decisions of the European Court of Human Rights are binding on the territory of Ukraine. Adherence to these decisions of the Council of Europe, the European Court of Human Rights, and following other recommendations of the
Council of Europe brings Ukraine closer to EU standards (Yurinets, 2015, p. 82).

In 2014, then-US Vice President Joe Biden paid a visit to Kyiv. In his speech, the politician noted that corruption is a "cancer" of Ukrainian society (Wilkinson, 2019).

Allegations of the absolute eradication of this phenomenon in the state seem questionable. The main task of the government, in our opinion, is to minimize corruption. One of the key elements in the fight against corruption is the creation of an effective system of anti-corruption bodies and a regulatory framework for their proper interaction.

E. Dimant and T. Schulte note the important role of establishing an effective system of anti-corruption institutions. Scholars argue that institutions play an important role both in providing a sound legal environment and in promoting the business of individual companies (Dimant, 2016, p. 68). Institutions that operate inefficiently lead to a loss of public confidence, which is why they play a particularly important role in combating corruption (Dreher, 2004).

In order to analyze this issue in detail, first of all, we propose to analyze the legal nature and historical origins of corruption.

\section{The concept of "corruption"}

The definition of "corruption" is formalized in the current legislation of Ukraine. The legislator in Article 1 of the Law of Ukraine "On Prevention of Corruption" defines the term "corruption" as the use of a person specified in part one of Article 3 of this Law (persons authorized to perform state or local government functions; persons who for the purposes of this Law are equated to persons authorized to perform the functions of the state or local self-government, persons who permanently or temporarily hold positions related to the performance of organizational or administrative duties, or specially authorized to perform such duties 
in legal entities of private law regardless of the organizational and legal form, as well as other persons who are not officials and who perform work or provide services in accordance with the contract with the enterprise, institution, organization - in cases provided by this Law, candidates for President of Ukraine and candidates for People's Deputies of Ukraine, registered in the manner prescribed by law, provided to her by officials powers or related opportunities for the purpose of obtaining an improper benefit or accepting such benefit or accepting a promise/offer of such benefit for oneself or others or, respectively, a promise/offer or providing an improper benefit to a person referred to in part 1 of Article 3 of this Law, or at its request, to other natural or legal persons in order to persuade this person to illegally use the official powers granted to him or her.

There is no consensus among scholars on the nature of corruption. The term "corruption" comes from the Latin word "corumpere", which literally translates as "damage", "abuse" (Friedrich, 1967).

Most foreign scholars conclude that the very etymology of the concept of "corruption" is quite ambiguous.

Machiavelli defined the term "corruption" as a process that "gradually destroyed the virtue (virtu) of citizens" (Heidenheimer, 2017).

According to the famous GermanAmerican political scientist K. Friedrich, "any attempt to analyze the concept of corruption will contradict the fact that in English and other languages the word "corruption" has historically had completely different meanings and connotations" (Friedrich, 1967).

There are 9 meanings of the term "Corruption" in the Oxford English Dictionary, of which only one can be used in a political context: "corruption is a breach or non-performance of public duties through bribery or other forms of bribery; the use or existence of corrupt practices, especially in the state, corporations, etc." (The Oxford English Dictionary).

J. Bryce, an English academic, lawyer, and diplomat, defined corruption in three senses, namely: bribery of civil servants (cash payment); another type of bribery of civil servants; as speculation with documents; as speculation for the benefit of candidates. The main element of corruption is bribery of civil servants (Bryce, 1921, pp. 149-150).

Also, there is a definition of corruption as behavior that deviates from the normal performance of duties by a public official to obtain "private (family or clan), material or status benefits" (Nye, 1967). This statement is accurate because corruption has harms all types of public life.

Ye. Nevmerzhytskyi considers corruption as a socio-political phenomenon. The scholar notes that the peculiarity of corruption is that officials of the legislative, executive, judicial branches of government, public associations, institutions, economic management organizations of all forms of ownership of their official position to obtain material values (Nevmerzhytskyi, 2008, p. 44). The social component, in our opinion, is an unconditional sign of corruption, as this phenomenon can be formed only in society.

0. Akimov considers corruption through the prism of psychology. He argues that corruption is not only a social but also a psychological and moral phenomenon. Because it does not exist separately from people, in particular their behavior or activities. "Corruption is a way of thinking that determines the way of life" (Akimov, 2014 , p. 181). In conclusion, the scientist cites the definition of corruption as a complex socio-psychological phenomenon that arises as a result of the implementation of power relations by authorized persons, who, in turn, illegally use power to meet personal needs. We agree with the position of the scientist on the presence of a psychological aspect in 
corruption, as a man as a biological being is primarily guided by self-interest.

Thus, in our opinion, the term "corruption" should be understood as a complex negative social phenomenon, which is due to historical and political processes in the state and psychological features of human thinking, which manifests itself in improper performance or non-performance of public administration to satisfy personal interests.

\section{Historical origins of corruption}

Such a social phenomenon as corruption has existed since ancient times, and the key goal of public authorities is to minimize this phenomenon. We propose to address the historical origins of corruption. It should be noted that the manifestations of corruption were first documented in the V-IV century BC. It was Aristotle who defined the concept of "corruption" as tyranny or an incorrect, corrupt form of monarchy.

During the existence of the Roman Empire, Mark Cicero blamed the governor of Sicily. He delivered a speech in the Roman Senate, which mentioned the extortion of art by the governor of Sicily from the people of Sicily (Gasparov, 1991, p. 29).

Later, Gaius Julius Caesar introduced punishment for bribing high-ranking officials. In particular, voter bribery in ancient Rome was quite common. Therefore, these actions were prohibited.

In the 5th century BC, Confucius noted that officials' concern for their families could lead to abuse of office (Soloviov, 2011).

The Middle Ages are characterized by the intensification of ecclesiastical law. Bishops were characterized as "hunters of money, not souls" (Soloviov, 2011).

In modern times, bribery of state justice has intensified with the help of influential relatives, famous people, etc. By using pressure or bribing high-ranking officials, they managed to hide the crimes they committed (Soloviov, 2011).

The first scientific studies of corruption in the science of political science began in the 60 s of the twentieth century. However, the term "political corruption" appeared in the late 19th century, and there is still no consensus on the term.

\section{The system of anti-corruption bodies of Ukraine}

As of today, Ukraine has reformed the current legislation in the context of Europeanization of Ukrainian legislation, in particular administrative law.

The problem of corruption has gained worldwide notoriety. World institutions are trying to actively oppose it. In the context of European integration processes, Ukraine is on a difficult path to counteract this phenomenon, as political and economic problems have a significant impact on the formation of Ukraine as a country with "European values" and the implementation of these values in the legal sphere.

According to Transparency International, Ukraine's Corruption Perceptions Index is 30 out of a possible 100. According to these data, Ukraine has returned to the level of 2017 and now occupies 126 th place out of 180 countries. Next to Ukraine in the ranking is Kyrgyzstan, Azerbaijan, and Djibouti. SRI leaders have not changed significantly. In the first place - New Zealand and Denmark, who scored 87 points each (Transparency International Ukraine, 2019).

The structure of an anti-corruption bodies of Ukraine includes: Verkhovna Rada of Ukraine (hereinafter referred to as the VRU); Cabinet of Ministers of Ukraine (hereinafter referred to as the CMU); Ministry of Justice of Ukraine (hereinafter referred to as the MJU); National Anticorruption Policy Council (hereinafter referred to as the NAPC); The National Agency on Corruption Prevention 
(hereinafter referred to as the NACP); National Anti-Corruption Bureau of Ukraine (hereinafter referred to as the NABU); Prosecutor's Office of Ukraine (hereinafter referred to as the PPO); Specialized Anti-Corruption Prosecutor's Office (hereinafter referred to as the SAP); National Police of Ukraine (hereinafter referred to as the NPU); State Bureau of Investigations (hereinafter referred to as the SBI); Courts of General Jurisdiction; High Anti-Corruption Court (hereinafter referred to as the HAC); Security Service of Ukraine (hereinafter referred to as the SSU); Asset Recovery and Management Agency (hereinafter referred to as the ARMA).

Verkhovna Rada of Ukraine, as the highest legislative body of Ukraine, adopts the Anti-Corruption Strategy and holds parliamentary hearings. The Committee on Anti-Corruption Policy carries out anticorruption examination of draft laws.

Cabinet of Ministers of Ukraine, as the highest executive body of Ukraine, approves the State Program for the Implementation of the Anti-Corruption Strategy.

Ministry of Justice of Ukraine carries out anti-corruption expertise of normative legal acts (with except laws, the examination of which is conducted by the Committee on Anti-Corruption Policy).

National Anticorruption Policy Council is an advisory body under the President of Ukraine, which provides recommendations on the development of anti-corruption policy in Ukraine. The National Council is headed by a chairman appointed by the President of Ukraine.

The Executive Secretary of the National Council is the Deputy Head of the Administration of the President of Ukraine, who is in charge of combating corruption.

The main tasks of the NAPC are: preparation and submission to the President of Ukraine of proposals on defining and updating the improvement of the anti-corruption strategy; implementation of a systematic analysis of the state of prevention and counteraction to corruption in Ukraine, the effectiveness of the implementation of anti-corruption strategy, measures taken to prevent and combat corruption; preparation and submission to the President of Ukraine of agreed proposals for improving coordination and interaction between entities that implement measures in the field of preventing and combating corruption; assessment of the state and promotion of the recommendations of The Group of States against Corruption (GRECO), the Organization for Economic Cooperation and Development (OECD), other leading international organizations to prevent and combat corruption, increase the effectiveness of Ukraine's international cooperation in this area; assistance in scientific and methodological support on preventing and combating corruption.

The National Council, in accordance with its main tasks: carries out a comprehensive assessment of the situation and trends in the field of preventing and combating corruption in Ukraine, analyzes national anti-corruption legislation and measures for its implementation; monitors and analyzes the effectiveness of the implementation of the anti-corruption strategy, makes proposals to improve the interaction of bodies responsible for its implementation; participates in the preparation for submission by the President of Ukraine to the VRU of draft laws in the field of prevention and counteraction to corruption; prepares proposals for bills, draft other regulations in the field of preventing and combating corruption; participates in the preparation of messages of the President of Ukraine to the people, annual and extraordinary messages to the VRU on the internal and external position of Ukraine in the implementation of anti-corruption policy; organizes the study of public opinion on issues considered by the National Council, provides coverage in the media of the results of its work; promotes scientific and 
methodological support on the prevention and combating of corruption, conducting analytical research, development of methodological recommendations in this area; prepares proposals to increase the effectiveness of Ukraine's international cooperation in the field of preventing and combating corruption (On the National Council for Anti-Corruption Policy: Decree of the President of Ukraine, 2014).

The National Anti-Corruption Bureau of Ukraine (NABU) is a state law enforcement body that detects, terminates, investigates and discloses corruption offenses, prevents the commission of new ones. The National Bureau is a legal entity governed by public law. NABU was established on the basis of the Law "On the National Anti-Corruption Bureau of Ukraine" of October 14, 2014.

The task of the NABU is to combat criminal corruption offenses committed by high-ranking officials (for example, the President of Ukraine, MPs, the Prime Minister of Ukraine, ministers, prosecutors, judges, etc.) authorized to perform state or local government functions. threat to national security (On the National AntiCorruption Bureau of Ukraine: Law of Ukraine, 2014).

The National Agency on Corruption Prevention (NACP) is the central executive body of Ukraine with a special status, which ensures the formation and implementation of state anti-corruption policy, formulates rules to prevent corruption and increase public sector transparency. The NACP is a collegial body with five members.

Prosecutor's Office of Ukraine (PPO) provides procedural support, in particular the management and support of the state prosecution in court in courts of general jurisdiction for the consideration of cases that fall under the jurisdiction of NABU, SBI, SSU.

The Specialized Anti-Corruption Prosecutor's Office (SAP) is an independent unit of the Office of the Prosecutor General that provides procedural guidance and support to the prosecution of the WACS in proceedings under NABU's jurisdiction.

State Bureau of Investigations (hereinafter referred to as the SBI) is a law enforcement agency that investigates certain corruption offenses, mostly committed by law enforcement or organized groups.

The National Police of Ukraine (NPU) investigates corruption offenses that are not within the jurisdiction of NABU or the DBR or corruption administrative offenses.

High Anti-Corruption Court (HAC). On June 7, 2018, the VRU adopted the Law "On the High Anti-Corruption Court" (On the High Anti-Corruption Court: Law of Ukraine, 2018). The creation of this institution of the judiciary has raised a number of controversial issues among politicians and scholars. The main reasons for the establishment of the HAC were the requirements of the European community for its establishment and the need to increase the efficiency of the judiciary in dealing with categories of cases under the jurisdiction of NABU-SAP.

As noted above, NGOs, officials of the European Union and the United States, the Venice Commission, Transparency International, and others have insisted on the establishment of an independent body of anti-corruption courts in Ukraine. In addition, the establishment of an independent anti-corruption court is one of the requirements of the International Monetary Fund. The Director of the NABU of Ukraine actively promotes the need to create a separate anti-corruption court, explaining the inefficiency of the newly formed anti-corruption bodies by the lack of an independent judiciary that would quickly and independently review materials submitted to it.

According to Article 125 of the Constitution of Ukraine, the judiciary in Ukraine is built on the principles of territoriality and specialization, and the 
creation of emergency and special courts is not allowed.

The competence of the HAC includes the consideration of cases opened by NABU or SAP against high-ranking officials for committing corruption offenses. The WACS Judicial Chamber has 27 judges. Cases are heard collectively (consisting of three judges), with the exception of the investigating court, which hears cases alone. According to the content, the consideration of the case by the said court chamber is a court of first instance. The parties have the right to appeal the decisions of the WACS Judicial Chamber to the WACS Appeals Chamber. The Appeals Chamber is also an independent body of 11 judges. The trial takes place collectively, consisting of three judges. Headed by WACS Chairman of WACS. Appeals against the decisions of the WACS Appeals Chamber are made to the panel of the Criminal Court of Cassation of the Supreme Court, which specializes exclusively in corruption cases.

Courts of general jurisdiction consider criminal proceedings on corruption criminal offenses under investigation by NPU, SBI, SSU; cases under administrative protocols drawn up by NACP and NPU; cases of bringing to civil responsibility for corruption offenses.

Security Service of Ukraine (SSU). The SSU is a special-purpose body endowed with law enforcement functions. The SBU is responsible for conducting operational and investigative activities, including corruption offenses.

Asset Recovery and Management Agency (ARMA) is an executive body responsible for identifying and tracing assets derived from corruption offenses and managing such assets (as long as they are under arrest).

Based on the above, it can be concluded that in Ukraine there are 4 institutions with anti-corruption powers, in particular, responsible for the formation of anti-corruption policy and prevention of corruption (The National Agency on Corruption Prevention, Verkhovna Rada of Ukraine, Cabinet of Ministers of Ukraine, Ministry of Justice of Ukraine, National Anticorruption Policy Council); 7 institutions investigating corruption and corruption-related offenses (The National Agency on Corruption Prevention, State Bureau of Investigations, Prosecutor's Office of Ukraine, Specialized AntiCorruption Prosecutor's Office, National Police of Ukraine, Security Service of Ukraine, National Asset Recovery and Management Agency); 2 institutions responsible for the administration of justice (High Anti-Corruption Court and courts of general jurisdiction).

Financing. According to the State Treasury Service and other available sources, as of April 30, 2020, state funding for the maintenance of anti-corruption bodies in Ukraine has been allocated to ARMA - UAH 30.7 million, HAC - UAH 60.3 million, SBI - UAH 174.1 million, NABU UAH 238.9 million, NACP - UAH 116 million, SAP - UAH 18.4 million, SSU - UAH 2 billion 625.9 million.

In total, UAH 3 billion 264.3 million is allocated to combat corruption. (more than 115 million US dollars).

\section{International experience}

The creation of a body of the judiciary, whose activities are aimed at combating corruption in Ukraine is borrowed from world experience. The first anti-corruption court was established in the Philippines (1979). An anti-corruption court was established in Nepal in 1999, and in Indonesia and Pakistan in 2002. In Europe, anti-corruption courts are in place in Croatia (2008), Slovakia (since 2005) and Bulgaria (since 2017). Today, anticorruption courts operate in only 20 countries, including Afghanistan, Bangladesh, Botswana, Burundi, Cameroon, Indonesia, Kenya, Nepal, Pakistan, Palestine, the Philippines, Senegal, and Uganda (the so-called "third world" countries). 
The Republic of Croatia. In Croatia, the anti-corruption system is based on the Office for Combating Corruption and Organized Crime (USKOK). In 2009, Judicial Divisions were established for criminal proceedings within the competence of USCOC. The specialized anti-corruption court has primary jurisdiction over corruption cases, and appeals are heard in the Supreme Court. Anti-corruption courts hear cases of high-level corruption and organized crime. Pursuant to Article 32 of the Law on the Office for the Suppression of Corruption and Organized Crime, the Judicial Departments for Criminal Proceedings under the Jurisdiction of the USCOC have been established in the District and Municipal Courts of Osijek, Rijeka, Split and Zagreb. Judges of the divisions are appointed by the chairman of the court on an annual basis after the relevant decision of the court council (Law on the Office for the Suppression of Corruption and Organized Crime, 2001).

The Republic of Bulgaria. In Bulgaria, the anti-corruption court is a universal parallel court, as the system of anticorruption courts includes both the court of first instance - the Specialized Criminal Court and the Court of Appeal - the Specialized Criminal Court of Appeal. The Supreme Court of Cassation acts as a cassation instance (Stvorennya ta diyal'nist' antykoruptsiynykh sudiv $u$ Bolhariyi, Slovachchyni ta Khorvatiyi Informatsiyna dovidka, pidhotovlena Yevropeys'kym informatsiynodoslidnyts'kym tsentrom na zapyt narodnoho deputata Ukrayiny)

The Special Criminal Court of Bulgaria hears cases of organized crime along with corruption. The Special Criminal Court of Slovakia hears, in addition to corruption and money laundering cases, cases of organized crime and premeditated murder.

The creation of an anti-corruption court was immediately criticized by judges and NGOs. Given that Bulgaria is one of the most corrupt countries in Europe and, accordingly, the high level of corruption in this country today, it is obvious that the anti-corruption court

It should be noted that the AntiCorruption Court of Bulgaria did not justify the purpose of its creation and did not become a catalyst for overcoming corruption in the country.

The Slovak Republic. The specialized anti-corruption court has primary jurisdiction over corruption cases, and appeals are heard in the Supreme Court. The anti-corruption court was formed of new judges. The legislator enshrined a number of guarantees and rights, such as: high judicial remuneration, personal protection, protection of judges. In Slovakia, there has been a problem with the severance of local ties between judges, lawyers, prosecutors and organized crime. During the first years of the anti-corruption court, certain results were achieved: special knowledge was accumulated, some local criminal ties were severed, and several cases were successfully completed.

There was opposition from politicians and judges of general courts, in connection with which the law on specialized anticorruption court was repealed in 2009 due to a constitutional appeal. However, due to public demands, the court resumed work the same year.

The grounds for the constitutional submission were: high salaries of judges of a specialized court, which was discrimination against other judges; security screening for judges, the requirements of which did not comply with the principle of independence of the judiciary; personal jurisdiction of the court over high-ranking officials.

Today, the specialized court of Slovakia consists of 14 judges, and the specialized prosecutor's office consists of 19 prosecutors. This court hears the most socially dangerous categories of cases: premeditated murders, economic offenses involving more than 6.6 million euros, serious crimes committed by criminal, terrorist groups and extremist crimes. 
Thus, each legal system has its own specifics. In one case, anti-corruption courts are courts of first instance, whose appeals against decisions go immediately to the country's Supreme Court (Croatia and Slovakia). Bulgaria has a parallel system of anti-corruption courts (court of first instance and appellate court). Most anti-corruption courts deal with a wide range of corruption and corruption-related offenses. In addition, some of the specialized courts classified as anticorruption courts actually have broader jurisdiction, covering not only corruption and corruption-related economic crimes, but also other serious crimes. For example, in Croatia, courts have jurisdiction not only over high-level corruption offenses, but also over organized crime. The jurisdiction of the Specialized Criminal Court of Bulgaria (and the relevant Court of Appeal, the Specialized Criminal Court of Appeal) similarly covers organized crime and corruption. Jurisdiction 7 of the Specialized Criminal Court in Slovakia extends to organized crime and premeditated murder, as well as corruption and money laundering.

Denmark is one of the leading countries in the world as the least corrupt country. It is in Denmark that the implementation of anti-corruption laws at the state level and the high legal awareness of citizens are most effective.

The most effective measure to prevent corruption in Denmark is the Danish Law on Corruption, adopted in 2002. According to the law, the Danish government is obliged to publish information on its property and personal income every year. To prevent officials from using their official position for personal purposes, they are obliged to sell their shares in foreign companies.

Paragraph 20 of the Rules of Procedure of the Danish Parliament states that any Member has the right to receive information on the position of any Minister on a matter within his / her competence. In this regard, the parliament holds regular meetings at which ministers respond to inquiries from their colleagues about suspicions of bribery or lobbying the interests of any company.

DANIDA, an international development agency, has extensive experience in combating corruption in Denmark. Agreements concluded by this agency must be accompanied by the signing of a declaration of non-use of bribes. Failure to comply with the provisions on bribery leads to the termination of the contract and the agency's refusal to cooperate with the violator in the future. Besides to the standard anti-corruption regulations, the company has also launched a hotline that allows people to notify the company's management of the illegal use of finances (Anti-corruption bodies of European countries: key preventive mechanisms Enhanced Public Sector Transparency and Integrity Project, 2016).

Significant anti-corruption in Denmark is provided by the Danish Export Credit Agency. Applicants to the agency are required to sign a declaration of nonbribery, which implies a refusal to participate in corrupt practices. In case of breach of the signed agreements, which resulted in financial losses, the applicants are obliged to pay compensation to the agency. In addition, the applicant loses the right to cover losses under the guarantee issued by the agency earlier.

The main task of the Trade Council is to fight corruption in Denmark in foreign markets. The organization helps to conclude deals in international markets while maintaining the good reputation of Danish companies. The Council assists in resolving both ordinary business issues that require consultation and complex issues that cannot be resolved without the assistance of the local government. The Council pursues a policy of "absolute intolerance", which is a good example of non-acceptance of corruption for employees of the organization. 
Industrialization Fund for Developing Countries (IFU). The purpose of the fund is to help expand business abroad by investing in international companies in developing countries with the support of Denmark. The fund provides advisory services, participation in the authorized capital, loans, and guarantees on commercial terms for investments in the service sector. Speaking about how the staff of this organization fights corruption in Denmark, it should be noted that when signing loan and equity participation agreements, the fund actively uses typical anti-corruption provisions.

Slovenia. The system of anti-corruption bodies in Slovenia consists of the following:

- Commission for the Prevention of Corruption (CPC).

- Secretariat (legal, financial, and personnel functions; international cooperation and PR; analysis, investigation, and information security department).

- Bureau of Investigation and Supervision (investigation of corruption, conflict of interest, lobbying, other administrative investigations, collection and monitoring of property declarations, application of rules on conflict of interest, protection of informants, cooperation with law enforcement agencies and the prosecutor's office).

- Center for Prevention of Corruption and Integrity of the Civil Service (coordination of the National Action Plan to Combat Corruption; development of integrity plans (for institutions); development and implementation of anticorruption measures; examination of legislation, cooperation with CSOs, universities, research institutions).

- The Commission for the Prevention of Corruption of Slovenia enjoys the high trust and significant authority in society, according to a report by the National Agency for the Prevention of Corruption. This is one of the first institutions to start working with illegal lobbying of interests through a special database (Anti- corruption bodies of European countries: key preventive mechanisms - Enhanced Public Sector Transparency and Integrity Project, 2016).

Macedonia. The State Commission for the Prevention of Corruption is the main anti-corruption institution in Macedonia. It reviews all reports of suspected corruption: both those it has investigated on its own and media reports, complaints, and informants.

The Commission includes a Secretariat, which can be divided into the Human Resources and Internal Audit Sectors. The Human Resources Sector includes the Sector for the Prevention of Corruption and Conflicts of Interest, which includes: the Department for the Prevention of Corruption (in politics, public administration, public interest, economic sphere), the Department for Maintenance of Registers and Monitoring of Property (monitoring of the property, maintenance of registers, etc.), Department of Conflict of Interest Prevention (monitoring of the state conflict of the interest prevention program and collection of information on conflicts of interest). The internal Audit Sector includes the Sector of Program, Analytical Work, Financial and Administrative Issues, which includes the Department of International Programs and Analytics (programs, analytics, monitoring of the State Program for Prevention and Overcoming Corruption), the Department of Public Relations (Public Relations), Department of Financial, Administrative and Personnel issues (financial issues and budget preparation, IT, archiving) (Anticorruption bodies of European countries: key preventive mechanisms - Enhanced Public Sector Transparency and Integrity Project, 2016).

At the beginning of its establishment, the SCPC received public support, which provided an opportunity to legitimize its activities. However, political influence over the Commission has increased since 2007. As a result, this led to the loss of a clear position and influence of the SCPC. The 
SCPC's mandate covers exclusively the implementation and monitoring of the anticorruption strategy, monitoring of changes in property status, special training for civil servants, cooperation with public authorities and international institutions. Imperfect legislation, which is manifested in the absence of proportional punishment for the act, lack of deadline for filing an annual property declaration, lack of a clear list of civil servants, lack of a comprehensive online filing system and full automatic integration with other state registers to verify declarations.

Serbia. The Anti-Corruption Agency includes the following divisions: Civil Servants' Property and Revenue Department (Registers and Supervision Department), Complaints Department (Registration and Initiation Group, Complaints Department, Informant Protection Group), International Cooperation Department (Group EU Integration, International Projects Group), Political Finance Supervision Department (Financial Reporting Supervision Department, Legal Department), Prevention Department (Education, Civil Society and Analysis Department, Strategies Implementation Supervision Department, Plan Action and Legislation, Integrity Plans Division), General Affairs Division, Conflict of Interest Office (Conflict of Interest Division, Management Transfer Supervision Division), IT Group.

A positive aspect of this structure is the high awareness of the public about the mechanisms of prevention and supervision of the Anti-Corruption Agency through PR campaigns. At the same time, the high authority of the Anti-Corruption Agency does not fully meet the expectations of citizens due to limited powers. An imperfect regulatory framework creates shortcomings in the process of cooperation with other government agencies. Also, gaps in the legislation lead to a decrease in the effectiveness of the Anti-Corruption Agency in conducting inspections for signs of corruption offenses in the actions of certain persons. The Anti-Corruption Agency does not have the right to initiate proceedings on anonymous complaints, which also reduces the efficiency of the AntiCorruption Agency. The powers of the agency, in this case, are limited solely to the possibility of transmitting information on anonymous complaints to other government agencies (Anti-corruption bodies of European countries: key preventive mechanisms - Enhanced Public Sector Transparency and Integrity Project, 2016).

Latvia. Corruption Prevention and Combating Bureau of Latvia includes the following divisions: Civil Servants Control Division, Political Party Finance Control Division, Policy Planning Division, Office, Legal Division, Finance Division, Administrative Division, Internal Security Division, Criminal Intelligence Division, Investigation Division, intelligence support department.

A feature of the Corruption Prevention and Combating Bureau of Latvia is that. That they conduct dozens of training events (training) a year. Most of these activities are aimed at raising awareness of anti-corruption legislation, professional ethics rules, and internal institutional compliance mechanisms for civil servants. In addition to these measures, measures are also taken to raise public awareness of anti-corruption legislation: compliance and implementation of the law (Anti-corruption bodies of European countries: key preventive mechanisms - Enhanced Public Sector Transparency and Integrity Project, 2016).

The positive aspects of Latvia's experience with the institutional structure of the Corruption Prevention and Combating Bureau of Latvia include the preparation and implementation of an anticorruption strategy, conflict of interest management and training.

Romania. National Integrity Agency (NAD), which includes the Main Registration Service, the Personnel Service, 
the Economic Directorate, the five Integrity Verification Services, the General Directorate for Legal Affairs, Public Relations and Communications (Legislation Department, Judicial Service, communications, public relations and strategy, IT service, IT infrastructure management, service information management).

A positive aspect of the NAD's activity is that information from the media, responsible officials from government agencies can be a sufficient basis for initiating an investigation.

The effectiveness of this institution is confirmed by a significant number of winning lawsuits in favor of the NAD, initiating the process of returning assets to the state budget. However, it should be noted that there are legal conflicts that hinder the activities of the NAD (Anticorruption bodies of European countries: key preventive mechanisms - Enhanced Public Sector Transparency and Integrity Project, 2016).

\section{Activity of the High Anti-} Corruption Court and Other AntiCorruption Bodies of Ukraine

O. Prokhorenko emphasizes that the typical shortcomings of anti-corruption legislation are the lack of system and coherence of norms that could be the basis for the application of measures to combat corruption. In addition, the unstable political situation has a significant impact, which leads to staff turnover in the field of public administration (Prokhorenko, 2005).

We agree with this thesis of the scientist. Also, given the above, it should be noted that in addition to the lack of systemic and consistent norms, there is no effective system of anti-corruption bodies. The accumulation of bodies of different legal status, as practice shows, does not help to improve the situation in the country on the way to overcoming corruption. This fact necessitates taking into account the experience of countries with relatively low levels of corruption, countries that are rapidly improving indicators to combat corruption in order to Europeanize not only the current legislation of Ukraine, but also Europeanization of the mentality of the Ukrainian people to combat this phenomenon.

The UN and Council of Europe Conventions against Corruption define such criteria for the effectiveness of specialized anti-corruption bodies as independence, specialization, proper training and adequate resources.

Our most effective system of anticorruption institutions could be a system consisting of the following bodies:

Group I includes bodies endowed with anti-corruption powers, in particular responsible for the formation of anticorruption policy and prevention of corruption (with the absorption of the powers of the NAPC in terms of anticorruption strategy):

- Verkhovna Rada of Ukraine,

- Cabinet of Ministers of Ukraine,

- Ministry of Justice of Ukraine,

- National Anticorruption Policy Council.

Group II includes bodies investigating corruption and corruption-related offenses:

- NABU (taking into account the anti-corruption powers of the SBI and NACP).

- Prosecutor's Office (with the preservation of an independent unit of the Office of the Prosecutor General of the SAP)

- National Police of Ukraine.

Group III includes the bodies responsible for the administration of justice:

- Court (courts of general jurisdiction).

The feasibility of this system is as follows:

ARMA. It is stated that ARMA was established by analogy with asset recovery and management institutions that operate 
successfully in the EU Member States in accordance with the decision of the Council of the European Union № 2007/845 / JHA of 06 December 2007 and other acts of EU law. However, the legislator introduced the provision on ARMA without harmonizing the current system of anti-corruption institutions. The main powers of ARMA are to identify and search for assets that have been illegally removed from Ukraine as a result of corruption and other criminal offenses, as well as the need to introduce transparent and effective mechanisms for managing seized assets, as well as the formation and maintenance of the Unified State Register of Assets. arrested in criminal proceedings. It seems doubtful that with the large number of anticorruption institutions in Ukraine there was a real need to create ARMA, as the authority to identify and search assets by content can be attributed to operational and investigative activities, which in turn corresponds to the legal status of NABU or SBI. carries out operative-search measures. Regarding the maintenance and formation of the Unified Register of Assets, it should be noted that the NACP could perform these powers as of today, as the latter is responsible for the administration of the Unified State Register of declarations of persons authorized to perform state or local government functions; Unified State Register of Persons Who Have Committed Corrupt or Corruption-Related Offenses; Unified State Register of Financial Statements of Political Parties.

NACP. As practice and public opinion show, the NACP absolutely does not justify its obligations. The powers of the NACP are abstract, which in turn creates competition with the powers of the NABU and the SBI in terms of operational and investigative activities in relation to corruption offenses, for the commission of which a person is brought to administrative responsibility. The division of powers according to the degree of public danger is in itself nonsense, because when conducting an investigation, persons working in these bodies cannot knowingly find out all the circumstances that have legal significance.

NABU became the first anti-corruption body to have a significant range of powers. In our opinion, in order to comply with the anti-corruption strategy, it is advisable to expand the powers of NABU.

SBI is legally close to NABU. The difference is in the subjective composition of the persons in respect of whom these bodies are authorized to carry out intelligence activities. It seems questionable to create two bodies of similar legal nature, instead of expanding the NABU staff and expanding the powers, which would lead to the absence of problems with the distribution of jurisdiction and competence and reduce public funding.

HAC. The fact of the creation of HAC provoked a mixed reaction from society. The positive features of the newly established institution were to be independence, impartiality, high professionalism of the judiciary, the implementation of the principle of inevitability of punishment, and as a consequence, a significant reduction in corruption.

The main arguments for the inexpediency of the creation and inefficiency of HAC can be considered the following:

- Long-term consideration of cases that end with the appointment of a fairly lenient punishment or closure of cases due to the omission of time limits for prosecution;

- No need to create a specialized body of the judiciary for a specific category of cases;

- A small number of cases considered by HAC;

- Artificial creation of an additional vertical of courts.

The experience of Ukraine and foreign countries, which have established anticorruption courts, indicates that the expectations regarding the effectiveness of 
this anti-corruption body have not yet materialized. During the year of activity in the court proceedings there were almost 300 cases, in 16 of which he has already announced verdicts. However, there are no convictions for corruption at the highest level yet.

In early 2019, Transparency International Ukraine provided 12 recommendations that could improve Ukraine's performance in CPI. As of the end of the year, only 6 of them were implemented or partially implemented, and those in the last quarter of 2019.

Among them were the abolition of the SSU monopoly on wiretapping (removal of information from transport telecommunications networks) and the abolition of the state monopoly on examinations, which will avoid artificially delaying the investigation.

The Verkhovna Rada also regulated the procedure for handing over suspicion to special entities, as there were frequent cases of abuse by the defense. At the same time, the criminal procedure code still has provisions that negatively affect the quality and effectiveness of pre-trial investigations. In particular, detectives are still limited in their activities during the investigation, which is likely to adversely affect its completeness.

On June 6, 2019, the Constitutional Court of Ukraine declared unconstitutional the provisions of paragraph 5 of part one of Article 3, paragraph three of part three of Article 45 of the Law of Ukraine "On Prevention of Corruption" of October 14, 2014 № 1700 - VII as amended (hereinafter - Law № 1700), paragraph 2 of Section II "Final Provisions" of the Law of Ukraine "On Amendments to Certain Laws of Ukraine on Peculiarities of Financial Control of Certain Categories of Officials" of March 23, 2017 № 1975 - VIII (hereinafter - Law № 1975) on Electronic Declaration of Anti-Corruption Public Activists. The Court concluded that these provisions violated the constitutionally guaranteed freedom of political and public activity and could be used for persecution.

Four recommendations were partially implemented in Ukraine. On October 18, the law came into force, which began to reset the NACP. The agency lost its collegiality, and the head was elected with the participation of international experts. At the end of the year, the NACP received automated access to verify e-declarations of the 3 required registers that remained unconnected.

After the early parliamentary elections, on September 19, 2019, a bill in the field of public procurement was adopted. The new law came into force on April 19, 2020 and is harmonized with EU standards. At the same time, the issue of effective monitoring of procurement by the State Audit Office remains relevant.

The Verkhovna Rada provided for the possibility of privatizing 500 state-owned enterprises through the ProZorro.Sale electronic auction system. In October 2019, the Verkhovna Rada lifted the ban on the privatization of a number of state-owned enterprises.

In October 2019, the Bankruptcy Code came into force and the Cabinet of Ministers adopted a resolution on conducting electronic auctions for the sale of property of insolvent enterprises through the ProZorro.Sales system.

The practice of using open budgets is growing moderately. In particular, Ukraine has a state budget web portal for citizens. The government has agreed on the composition of supervisory boards in a number of state-owned enterprises, including the Ukrainian Seaports Administration, Boryspil International Airport, Ukrzaliznytsia, and Ukrhydroenergo. However, in the previous year, the process of establishing supervisory boards in local communities at utilities did not accelerate significantly (Transparency International Ukraine, 2019). 
The following recommendations were not implemented:

- Ensuring the effective operation of the register of beneficiaries;

- Strengthening control over the financing of political parties;

- Changing the method of forming judicial self-government bodies;

- Restoration of trust in the Specialized Anti-Corruption Prosecutor's Office.

Deprivation of the SSU and the National Police of powers in the fight against economic crime "Punish those responsible for organizing attacks on anticorruption activists".

Given the above, in our opinion, it would be appropriate to introduce the following system of anti-corruption bodies (Transparency International Ukraine, 2019).

Among the countries where bodies similar to the powers of the SSU are deprived of investigative functions are: Lithuania, Slovenia, Slovakia, Croatia, Montenegro. Cases where countries provide state security services to investigators are rare and the effectiveness of those powers has not been proven. I think we should start talking about the expediency of depriving the SSU of investigative functions, as evidenced by the experience of European countries.

We believe that the key point in the process of improving the effectiveness of the fight against corruption in Ukraine is the need to implement the experience of European countries in terms of informing and training civil servants in professional ethics, raising awareness and legal culture of citizens. In particular, Romania's experience in the adequacy of media information to verify the accuracy of information and conduct investigative actions can be considered useful. The high authority of anti-corruption bodies, as evidenced by the analyzed practice of the EU, determines the effectiveness of the fight against corruption.
On most information sites of anticorruption bodies, citizens ask questions about the legal nature and questions related to the procedure for appealing in case of corruption offenses. For example NABU. As a general rule, these authorities recommend that you first check whether the information is relevant to NABU detectives, after which the person should make sure that the information relates to NABU detainees, and only then call the hotline. It seems logical that not all citizens can properly qualify the act they have witnessed. The legislator was guided by the logic of creating such a complex system of anti-corruption bodies in order to avoid information leakage, impartiality of officials. However, the logical question is to protect the whistleblower and to preserve the confidentiality of the information communicated by the person to all bodies known to him due to low legal awareness.

Such a system of anti-corruption institutions will help to clearly establish powers, avoid conflicts of interest and bureaucratic schemes, increase the targeted use of budget funds, facilitate citizens' access to relevant bodies with complaints about corruption offenses, and eliminate the privileged status of corrupt officials in the administration of justice.

\section{CONCLUSIONS}

Therefore, based on the above, we can draw the following conclusions. Today, the activities of the Supreme Anti-Corruption Court and anti-corruption bodies of Ukraine in the context of Europeanization are aimed at overcoming corruption. The term "corruption" should be understood as a complex negative social phenomenon, which is due to historical and political processes in the state and psychological features of human thinking, which manifests itself in improper performance or non-performance by public administration officials to satisfy personal interests. The main task of the government, in our opinion, is not to overcome, but to minimize corruption. One of the key 
elements in the fight against corruption is the creation of an effective system of anticorruption bodies and a regulatory framework for their proper interaction. Based on the above, it can be concluded that in Ukraine there are 4 institutions with anti-corruption powers, in particular responsible for the formation of anticorruption policy and prevention of corruption (The National Agency on Corruption Prevention, (Verkhovna Rada of Ukraine, Cabinet of Ministers of Ukraine, Ministry of Justice of Ukraine, National Anticorruption Policy Council); 7 institutions investigating corruption and corruption-related offenses (National AntiCorruption Bureau of Ukraine, prosecutor's offices, Specialized Anti-Corruption Prosecutor's Office, National Police, State Bureau of Investigation, Security Service of Ukraine, Asset Recovery and Management Agency); 2 institutions responsible for the administration of justice and prosecution of persons for corruption (High AntiCorruption Court of Ukraine and courts of general jurisdiction).

Today, there are 20 countries in the world where anti-corruption courts have been established. Each legal system has its own specifics. In one case, anti-corruption courts are courts of first instance, whose appeals against decisions go immediately to the country's Supreme Court (the Republic of Croatia and the Slovak Republic). The Republic of Bulgaria has a parallel system of anti-corruption courts (court of first instance and appellate court). On the example of the analysis of the experience of European countries, the effectiveness of the creation of such a body remains questionable. The Supreme AntiCorruption Court in Ukraine has become a revolutionary step for Ukraine. The positive features of the newly established institution were to be independence, impartiality, high professionalism of the judiciary, the implementation of the principle of inevitability of punishment, and as a consequence, a significant reduction in corruption. However, as practice has shown, the main arguments for the inexpediency of the establishment and inefficiency of the HAC can be considered the following: no need to create a specialized body of the judiciary for a specific category of cases, a small number of cases considered by the HAC, the artificial creation of an additional vertical of courts.

The accumulation of bodies of different legal status, as shown by European and domestic practice, does not help to improve the situation in the country on the way to minimizing corruption. This fact necessitates taking into account the experience of countries with relatively low levels of corruption; countries that are rapidly improving indicators to minimize corruption in order to Europeanize not only the norms of current legislation of Ukraine, but also the Europeanization of the mentality of the Ukrainian people on the way to combat this phenomenon.

It was emphasized that the most effective system of anti-corruption institutions could be a system consisting of the following bodies: I group of bodies endowed with anti-corruption powers, in particular responsible for anti-corruption policy and corruption prevention (with absorption of NACP powers in terms of Anti-Corruption Strategy): The Verkhovna Rada of Ukraine, Cabinet of Ministers of Ukraine, Ministry of Justice of Ukraine, National Anticorruption Policy Council. Group II of bodies investigating corruption offenses and corruption-related offenses. NABU (taking into account the anticorruption powers of the SBI and NACP). Prosecutor's Office (with the preservation of an independent unit of the Office of the Prosecutor General of the SAP) National Police. III group of bodies responsible for the administration of justice. Court (courts of general jurisdiction).

With regard to ARMA, it should be noted that it is doubtful that with the large number of anti-corruption institutions in Ukraine there was a real need to create ARMA, as the authority to identify and 
search assets by content can be attributed to operational and investigative activities, which in turn the legal status of NABU or SBI, which directly carries out operational and investigative measures.

As for the SSU, it was found that among the countries where bodies similar to the powers of the SSU are deprived of investigative functions are: Lithuania, Slovenia, Slovakia, Croatia, Montenegro. Cases where countries provide state security services to investigators are rare and the effectiveness of those powers has not been proven. I think we should start talking about the expediency of depriving the SSU of investigative functions, as evidenced by the experience of European countries.

Given the above, we believe that a key point in the process of improving the effectiveness of the fight against corruption in Ukraine is the need to implement the experience of European countries also in terms of informing and training civil servants professional ethics, awareness and legal culture. In particular, Romania's experience in the adequacy of media information to verify the accuracy of information and conduct investigative actions can be considered useful. The high authority of anti-corruption bodies, as evidenced by the analyzed practice of EU countries (including Denmark), determines the effectiveness of the fight against corruption. Such a system of anticorruption institutions will help to clearly establish powers, avoid conflicts of interest and bureaucratic schemes, increase the targeted use of budget funds, facilitate citizens' access to relevant bodies with complaints about corruption offenses, and eliminate the privileged status of corrupt officials in the administration of justice.

\section{References}

Akimov, O. O. (2014). Psykholohichni aspekty proiaviv koruptsii $\mathrm{v}$ derzhavnomu upravlinni [Psychological aspects of corruption in government]. Derzhavne upravlinnia: teoriia ta praktyka, 1, 181-
188. Retrieved August 1, 2020, from: http://nbuv.gov.ua/UJRN/Dutp 201 4123 (in Ukrainian)

Antykoruptsiini orhany krain Yevropy: kliuchovi preventyvni mekhanizmy [Anticorruption bodies of European countries: key preventive mechanisms]: Zbirka-zvit krashchykh praktyk dlia Natsionalnoho ahentstva z pytan zapobihannia koruptsii. Proekt "Prozorist i dobrochesnist publichnoho sektoru" [Enhanced Public Sector Transparency and Integrity Project]. 2016. Retrieved August 1, 2020, from: http://www.dhrp.org.ua/images/ne wsarticles/20160219/Commission ua sma ll.pdf (in Ukrainian)

Betsa, I., \& Sheremetieva L. (2009). Osnovy poniattia "ievropeizatsiia" ta yoho sens u suchasnomu suspilstvi [Fundamentals of the concept of "Europeanization" and its meaning in modern society]. Yevropeizatsiia publichnoho administruvannia $\mathrm{v}$ Ukraini $\mathrm{v}$ konteksti yevropeiskoi intehratsii: Materialy naukovo-praktychnoi konferentsii (m. Dnipropetrovsk, 17 hrudnia 2009 r.). Dnipropetrovsk: DRIDU NADU (p. 36-39). Retrieved August 1, 2020,

from: http://www.dridu.dp.ua/konf/konf dridu/2009 12 17\%20konf.pdf $\quad$ (in Ukrainian)

Bryce, J. (1921). Modern Democracies. New York: Macmillan. 2 vols. Vol. 2. (pp. 149-150). Retrieved August 1, 2020, from: https://oll.libertyfund.org/titles/209 $\underline{0}$

Corruption Perceptions Index, CPI (2019). Transparency International Ukraine. Retrieved August 1, 2020, from: $\quad$ https://tiukraine.org/research/indeks-spryjnyattyakoruptsiyi-2019/(in Ukrainian)

Dimant, E., \& Schulte, T. (2016). The Nature of Corruption: An Interdisciplinary Perspective. German Law Journal, 17(1), 53-72.

doi: https://doi.org/10.1017/s207183220 0019684 
Dreher, A., Kotsogiannis, C., \& McCorriston, S. (2004). Corruption Around the World: Evidence from a Structural Model. SSRN Electronic Journal. doi: http://dx.doi.org/10.2139/ssrn.55594 $\underline{6}$

Friedrich, Carl J. (2017). Corruption Concepts in Historical Perspective / Edited by A. J. Heidenheimer, M. Johnston. Political Corruption: Concepts and Contexts. Third Edition. New York: Routledge, 15-24 (850 p).

Gasparov, M. L. (ed.) (1991). Antichnaya poetika. Ritoricheskaya teoriya i literaturnaya praktika [Antique poetics. Rhetorical theory and literary practice]: sbornik. Moskva: Nauka, 1991. (254 p) (in Russian)

Heidenheimer, A. I., \& lohnston, M. (2017). Political Corruption: Concepts and Contexts. 3rd Edition. New York: Routledge (850

p.). doi: https://doi.org/10.4324/9781315126 $\underline{647}$

Law on the Office for the Suppression of Corruption and Organized Crime (Law of Croatia), № 1497, NN 88/2001, from:https://www.zakon.hr/z/166/Zakon -o-Uredu-za-suzbijanje-korupcije-i-

organiziranog-kriminaliteta

Mikhel, D. O. (2011). Vyznachennia poniattia protsesu "ievropeizatsiia" ta yoho vplyv na suchasne suspilstvo [Definition of the concept of the process of "europeanization" and its impact on modern society]. Naukovi pratsi [Chornomorskoho derzhavnoho universytetu imeni Petra Mohyly]. Ser.: Politolohiia, 162(150), 22-25. Retrieved August 1, 2020, from: http://nbuv.gov.ua/U/RN/Npchdupo $\underline{120111621507}$

Nevmerzhytskyi, Ye. V. (2008). Koruptsiia v Ukraini: prychyny, naslidky, mekhanizmy protydii [Corruption in Ukraine: causes, consequences, countermeasures]. Kyiv: KNT (363 p.). Retrieved August 1, 2020, from:
nbuv.gov.ua/ulib/item/UKR0002185 (in Ukrainian)

Nye, J. S. (1967). Corruption and Political Development: A Cost-Benefit Analysis. American Political Science Review, 61(2), 417-427. doi: https://doi.org/10.2307/1953254

On the High Anti-Corruption Court (Law of Ukraine). № 2447-VIII 07.06.2018. Retrieved August 1, 2020, from: https://zakon.rada.gov.ua/laws/sho w/2447-19\#Text (in Ukrainian)

On the National Anti-Corruption Bureau of Ukraine (Law of Ukraine). 14.10.2014, № 1698-VII. Retrieved August 1 , 2020,

from: https://zakon.rada.gov.ua/laws/sho w/1698-18\#Text (in Ukrainian)

On the National Council for AntiCorruption Policy (Decree of the President of Ukraine). 14.10.2014, № 808/2014. Retrieved August 1, 2020, from: https://zakon.rada.gov.ua/laws/sho w/808/2014\#Text (in Ukrainian)

Prokhorenko, O. Ya. (2005). Koruptsiia po-ukrainsky (sutnist, stan, problemy) [Corruption in Ukrainian (essence, state, problems)]. Kyiv: Vydavnytstvo NADU (166 p.) (in Ukrainian)

Soloviov, V. (2011). Istorychna geneza koruptsii [Historical genesis of corruption]. Naukovi zapysky Instytutu zakonodavstva Verkhovnoi Rady Ukrainy, 5(8), 22-26 (in Ukrainian)

Stvorennya ta diyal'nist' antykoruptsiynykh sudiv u Bolhariyi, Slovachchyni ta Khorvatiyi Informatsiyna dovidka, pidhotovlena Yevropeys'kym informatsiyno-doslidnyts'kym tsentrom na zapyt narodnoho deputata Ukrayiny [Creation and activities of anti-corruption courts in Bulgaria, Slovakia and Croatia. Information note prepared by the European Information Center on request of the people's deputy of Ukraine], from: http://euinfocenter.rada.gov.ua/uplo ads/documents/29287.pdf (in Ukrainian)

The Oxford English Dictionary. Oxford Dictionaries. Retrieved August 1, 2020, 
from: https://languages.oup.com/research Loxford-english-dictionary/

Wilkinson, T., \& Loiko, S. L. (2019). Here is what Joe Biden actually did in Ukraine. Los Angeles Times (oct. 5, 2019). Retrieved August 1, 2020, from: https://www.latimes.com/politics/st ory/2019-10-05/bidens-visits-to-ukraineunder-scrutiny
Yurinets, Y. (2015). Yevropeizatsiia administratyvnoho prava Ukrainy: teoretyko-metodolohichni zasady [Europeanization of administrative law in Ukraine: theoretical and methodological foundations]. Yurydychnyi visnyk. Povitriane i kosmichne pravo, 4, 80-87. Retrieved August 1, 2020, from: http://nbuv.gov.ua/UJRN/Npnau 20 $\underline{15417}$ (in Ukrainian) 